\title{
Pathways to Judicial Power in Transitional States: Perspectives from African Courts Rachel L Ellett - ERRATUM
}

\section{Mark Fathi Massoud}

DOI: http://dx.doi.org/10.1017/S0021855315000170 Published online: 7 September 2015

In the above mentioned book review [1] the spelling of the author's name was incorrect and has since been corrected. The reviewer apologises for this error.

\section{Reference}

[1] Mark Fathi Massoud. Review of 'Pathways to Judicial Power in Transitional States: Perspectives from African Courts' Journal of African Law, published online: 7 September 2015. doi:10.1017/S0021855315000170. 